Journal of Community Based Environmental Engineering and Management, 2019, Vol. 3, No. 2: 79-86

\title{
KUALITAS AIR WADUK JATILUHUR DI PURWAKARTA TERHADAP PENGARUH KERAMBA JARING APUNG
}

\author{
Purnomosutji Dyah Prinajati* \\ Jurusan Teknik Lingkungan, Universitas Sahid
}

\begin{abstract}
Abstrak
Waduk Jatiluhur adalah bendungan multiguna pertama di Indonesia yang disediakan 12,9 miliar $\mathrm{m}^{3} /$ tahun potensi air. Dalam operasi sekitar 15 tahun terakhir dengan aktivitas industri, meningkatkan populasi, mengurangi kondisi DAS dan lebih meningkatkan keramba jaring apung di area reservoir Jatiluhur yang ditunjukkan dengan adanya penurunan kualitas bendungan air. Tujuan penelitian ini adalah untuk mengetahui kualitas air dan tingkat pencemaran air di waduk Jatiluhur yang disebabkan keramba jaring apung. Penelitian ini dilakukan dalam lima titik pengambilan sampel: Titik 1: Kerenceng; Titik 2: Jamaras; Titik 3: Bojong; Titik 4: Sodong; Titik 5: Parung Kalong. Parameter kualitas air yang diukur adalah oksigen terlarut dan tingkat beban pencemaran. Hasil dari penelitian menunjukkan bahwa keramba jaring apung berpengaruh terhadap penurunan kualitas air di waduk Jatiluhur, terdapat peningkatan beban pencemaran air di waduk Jatiluhur yaitu 512,89 mg/detik.
\end{abstract}

Kata kunci: Waduk Jatiluhur, keramba jaring apung, kualitas air

\section{Pendahuluan}

Bendungan Jatiluhur merupakan bendungan terbesar di Indonesia. Bendungan ini disebut pula bendungan Ir. $H$. Djuanda, dengan panorama danau seluas 8.300 ha. Bendungan ini mulai dibangun sejak tahun 1957 oleh kontraktor asal Perancis, dengan potensi air yang tersedia sebesar 12,9 milyar $\mathrm{m}^{3} /$ tahun dan merupakan waduk serbaguna pertama di Indonesia.

Di dalam Bendungan Ir. H. Djuanda, terpasang 6 unit turbin dengan daya terpasang sebesar 187 MW dengan produksi tenaga listrik rata-rata 1.000 juta kwh setiap tahun, dikelola oleh PT. PLN (Persero). PLTA dibangun memotong sungai Citarum sebagai sungai terbesar wilayah

\footnotetext{
${ }^{*}$ Penulis Korespondensi:

E-mail: iinsoekandar@gmail.com

Diterima pertama kali: 29 Agustus 2019

Direvisi : 30 Agustus 2019

Disetujui untuk publikasi: 31 Agustus 2019
}

Provinsi Jawa Barat. Selain dari itu Bendungan Jatiluhur memiliki fungsi penyediaan air irigasi untuk 242.000 ha sawah (dua kali tanam setahun), air baku air minum, budidaya perikanan dan pengendali banjir yang dikelola oleh Perum Jasa Tirta II, pengendalian banjir di Kabupaten Karawang dan Bekasi, pasok air untuk rumah tangga, industri dan penggelontoran kota, pasok air untuk budidaya perikanan air payau sepanjang pantai utara Jawa Barat seluas 20.000 ha, dan pariwisata.

Selama operasi dalam 15 tahun terakhir ini kondisi lingkungan masih baik dan tidak ada permasalahan pada PLTA, namun dengan adanya aktifitas industri, bertambahnya penduduk, penurunan kondisi DAS yang berpengaruh terhadap besarnya pencemaran yang masuk ke Sungai Citarum. Aktivitas manusia seringkali menimbulkan pencemaran pada perairan (Suharto dkk., 2019). Ditambah lagi di bagian hulu ada kegiatan budidaya ikan dengan jaring apung di perairan waduk 
menyebabkan kondisi lingkungan menjadi sangat menurun yang ditunjukkan dengan tingkat eutrofikasi dan produksi racun yang terdeteksi pada dasar reservoir dan di outlet waduk Ir. H. Djuanda (Anas dkk., 2016).

Kondisi tersebut menyebabkan tidak optimalnya PLTA Ir. H. Djuanda akibat dari muatan-muatan polusi yang tinggi dan gas yang ditimbulkan seperti $\mathrm{H}_{2} \mathrm{~S}$ dan $\mathrm{CO}_{2}$ agresif, berakibat pada peralatan elektrikal, pisau-pisau turbin, katup, kartu elektronik dan unit terminal peralatan kontrol menjadi korosi sehingga membutuhkan penggantian peralatan dan adanya upaya-upaya untuk mengendalikan dampak pencemaran tersebut. Masalah aktifitas industri, bertambahnya penduduk, penurunan kondisi DAS dan kegiatan budidaya ikan di bagian hulu perairan waduk akan membawa dampak kondisi lingkungan menjadi sangat menurun di wilayah bendungan Ir. H. Djuanda; populasi keramba jaring apung (KJA) saat ini sudah melebihi batas (Deswati dkk., 2018) yang ditentukan sehingga semakin meningkat pula limbah dari kegiatan KJA tersebut; penurunan kualitas air di sekitar bendungan Ir. H. Djuanda. Dari hal tersebut timbul permasalahan tingkat pencemaran yang terjadi di wilayah Waduk Jatiluhur, bagaimana cara untuk mengendalikan populasi KJA yang semakin meningkat, bagaimanakah upaya untuk memperbaiki kualitas air di sekitar bendungan.

Tujuan Penelitian ini untuk menghitung konsentrasi DO air waduk di Inlet dan di Outlet Keramba Jaring Apung (KJA); menghitung tingkat pencemaran air Waduk Jatiluhur berdasarkan parameter Dissolved Oxygen (DO); dan membahas perbedaan kualitas air di Inlet dan di Outlet Waduk Jatiluhur yang ditempati KJA. Hasil penelitian yang dilakukan di Bendungan Ir. H. Djuanda diharapkan dapat memberikan sumbangsih bagi pengelola bendungan Ir. H. Juanda Perum Jasa Tirta II, dapat memberikan informasi dan menjadi bahan evaluasi terhadap upaya pengendalian pencemaran lingkungan di sekitar bendungan Ir. H. Djuanda sehingga dapat mengurangi dampak kerusakan lingkungan dan kerusakan peralatan PLTA yang merupakan aset penting bagi Badan Usaha Milik Negara sebagai pengelola.

Ruang lingkup ini dibatasi pada masalahmasalah terjadinya penurunan kualitas lingkungan dan tingkat pencemaran lingkungan yang terjadi di sekitar bendungan Ir. H. Djuanda sebelum melewati KJA dan sesudah melewati wilayah KJA melalui parameter DO dan upayaupaya perbaikan yang dilakukan pengelola bendungan yaitu Perum Jasa Tirta II.

\section{Metodologi Penelitian}

Penelitian ini bersifat non eksperimen, data yang diambil adalah data primer juga sekunder untuk mengetahui kualitas air waduk Ir. H. Juanda (Waduk Jatiluhur) sebelum melewati KJA, saat didaerah KJA dan sesudah melewati KJA.

Lokasi penelitian di Bendungan Ir. H. Juanda (Waduk Jatiluhur), Purwakarta, Jawa Barat. Waktu penelitian pengumpulan data berupa observasi lapangan dan penelaahan dokumen. Yang dianalisis adalah data primer hasil observasi secara langsung dan data sekunder yang telah dipublikasikan atau hasil pengamatan dari Perusahaan Umum Jasa Tirta II Jatiluhur, Purwakarta.

Morfologi yang terbentuk di Bendungan Ir. H. Djuanda (Waduk Jatiluhur) dari hasil kegiatan tektonik dan vulkanisme, dilanjutkan proses erosi dan sedimentasi. Kondisi morfologi Waduk Jatiluhur terbagi atas morfologi gununggunung batu andesit, perbukitan, dataran daerah hulu anak-anak sungai di DAS Citarum dan lembah-lembah curam terbentuk dari morfologi letusan gunung berapi ribuan tahun yang lalu yang memiliki karakteristik bebatuan andesit yang keras dan kokoh dengan elevasi ketinggian rata-rata antara $500-1000$ meter di atas permukaan air laut, kemiringan lereng di kaki 5 $15 \%$, ditengah $15-30 \%$, dan di puncak $30-$ 
90\%. Pola aliran waduk sejajar dan radier, umumnya merupakan daerah resapan utama air tanah dangkal dan dalam. Batuan penyusun berupa endapan bekas gunung api tua yang berasal dari gunung Burangrang dan Gunung Sunda, yaitu berupa tuff, lava andesit basalitis, breksi vulkanik, dan lahar. Pada bagian permukaan batuan itu terdapat endapan hasil erupsi gunung api muda yang meliputi batu pasir, lahar, lapili, breksi lava basal, aglomerat tufan, pasir tufa, lapili dan laca scoria.

Wilayah Waduk Jatiluhur didominasi oleh dataran, perbukitan bergelombang lemah dan terjal dan morfologi tubuh gunung-gunung api tua dan muda disekitarnya dengan elevasi antara $500-1000$ m dpl.

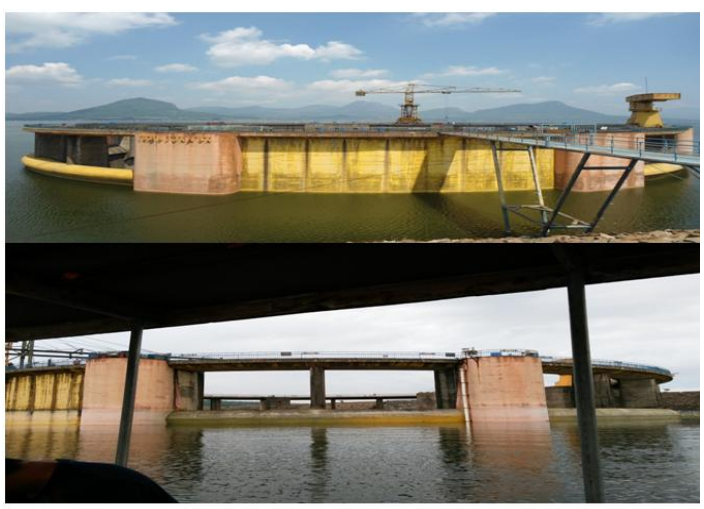

Gambar 1.Bendungan Utama Ir. H. Djuanda

Berikut keadaan umum di lokasi penelitian mulai dari titik sampling nomor 1 sampai titik sampling nomor 5 yang terletak di Waduk Jatiluhur, Jawa Barat. Tabel 1 memperlihatkan mengenai lokasi titik sampling disertai dengan koordinat posisi tiap titik.

Gambar 2 menunjukkan peta pengambilan sampel air waduk. Titik 1 berada di lokasi paling utara waduk yaitu di Desa Kerenceng, Titik 2 berada di Desa Jamaras, Titik 3 berada di Desa Bojong, Titik 4 berada di Desa Sodong, sedangkan Titik 5 berada paling selatan yaitu di Desa Parung Kalong.
Tabel 1. Lokasi Sampling Air Waduk Ir.H.Djuanda

\begin{tabular}{|c|c|c|c|}
\hline No & Lokasi & Alamat & Koordinat GPS \\
\hline 1 & $\begin{array}{l}\text { Kerenceng (Inlet } \\
\text { KJA) }\end{array}$ & $\begin{array}{l}\text { Ds. Kerenceng, Kec. } \\
\text { Jatiluhur, Kab. Purwakarta }\end{array}$ & $\begin{array}{l}\mathrm{S}=06^{0} 32^{\prime} 46.8^{\prime \prime} \mathrm{LS} \\
\mathrm{E}=107^{\circ} 18^{\prime} 29.9^{\prime \prime} \mathrm{BT}\end{array}$ \\
\hline 2 & $\begin{array}{l}\text { Jamaras (daerah } \\
\text { dekat KJA) }\end{array}$ & $\begin{array}{l}\text { Ds. Jamaras, Kec. Jatiluhur, } \\
\text { Kab. Purwakarta }\end{array}$ & $\begin{array}{l}\mathrm{S}=06^{0} 34^{\prime} 54.7^{\prime \prime} \mathrm{LS} \\
\mathrm{E}=107^{\circ} 18^{\prime} 07.9^{\prime \prime} \mathrm{BT}\end{array}$ \\
\hline 3 & $\begin{array}{l}\text { Bojong (daerah } \\
\text { KJA) }\end{array}$ & $\begin{array}{l}\text { Ds. Bojong, Kec. Jatiluhur, } \\
\text { Kab. Purwakarta }\end{array}$ & $\begin{array}{l}\mathrm{S}=06^{0} 38^{\prime} 36.8^{\prime \prime} \mathrm{LS} \\
\mathrm{E}=107^{\circ} 17^{\prime} 59.5^{\prime \prime} \mathrm{BT}\end{array}$ \\
\hline 4 & $\begin{array}{l}\text { Sodong (dekat } \\
\text { Outlet KJA) }\end{array}$ & $\begin{array}{l}\text { Ds. Sodong, Kec. Jatiluhur, } \\
\text { Kab. Purwakarta }\end{array}$ & $\begin{array}{l}\mathrm{S}=06^{\circ} 40^{\prime} 25.4^{\prime \prime} \mathrm{LS} \\
\mathrm{E}=107^{\circ} 19^{\prime} 24.4^{\prime \prime} \mathrm{BT}\end{array}$ \\
\hline 5 & $\begin{array}{l}\text { Parung Kalong } \\
\text { (Oulet KJA) }\end{array}$ & $\begin{array}{l}\text { Ds. Parung kalong, Kec. } \\
\text { Jatiluhur, Kab. Purwakarta }\end{array}$ & $\begin{array}{l}\mathrm{S}=06^{\circ} 40^{\prime} 45.8^{\prime \prime} \mathrm{LS} \\
\mathrm{E}=107^{\circ} 20^{\prime} 49.5^{\prime \prime} \mathrm{BT}\end{array}$ \\
\hline
\end{tabular}

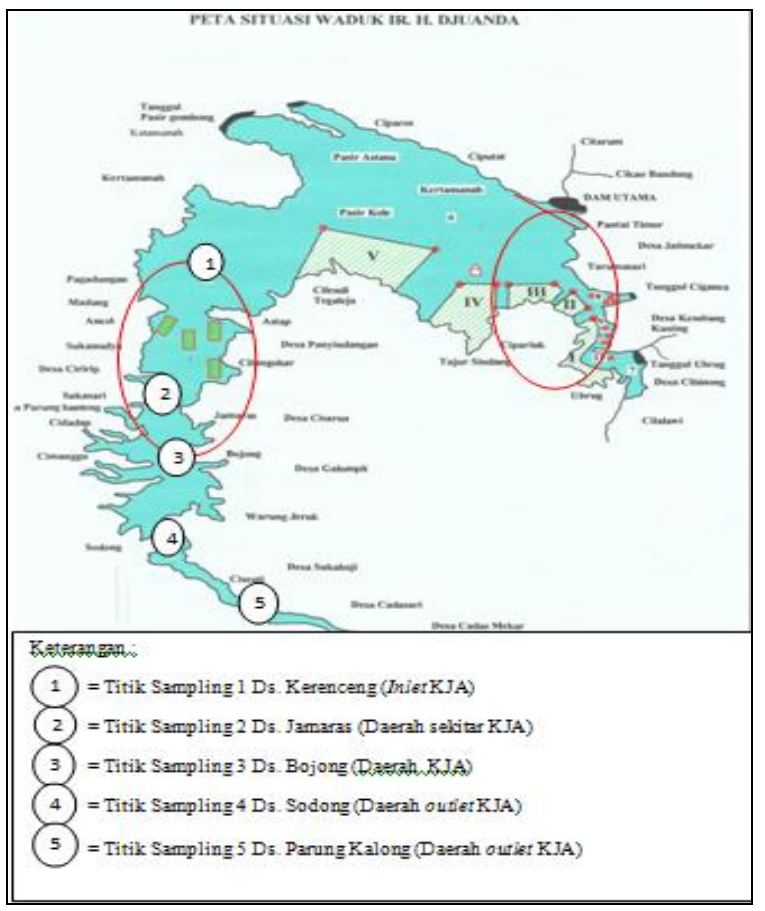

Gambar 2. Peta Lokasi Pengambilan Sampel Air Waduk

\section{Hasil dan Pembahasan}

Menurut Peraturan Pemerintah Nomor 82 Tahun 2001 tentang Pengelolaan Kualitas Air dan Pengendalian Pencemaran Air, klasifikasi mutu air kelas 1 yaitu air yang peruntukannya dapat digunakan untuk air baku air minum, dan atau peruntukan lain yang mempersyaratkan mutu air 
yang sama dengan kegunaan tersebut harus $\geq 6$ mg/L. Jika tidak sesuai dengan baku mutu yang dipersyaratkan maka air tersebut tidak bisa digunakan langsung sebagai air baku air minum.

Kehidupan makluk hidup di dalam air (tumbuhan dan biota air) bergantung dari kemampuan air untuk mempertahankan konsentrasi DO minimal yang diperlukannya. Oksigen terlarut dapat berasal dari proses fotosintesis tumbuhan air dan dari udara yang masuk ke dalam air (Manik, 2009). Semakin tinggi konsentrasi DO terhadap air maka kualitas air semakin baik.

Berdasarkan hasil pengukuran di lima titik sampling tampak bahwa nilai oksigen terlarut (DO) dari mulai tahun 2014-2019mengalami penurunan dan menunjukkan konsentrasi yang rata-rata kurang dari baku mutu kelas I. Dari tahun ke tahun konsentrasi DO semakin menurun ditunjukkan dengan angka konsentrasi DO yang semakin rendah tiap tahunnya. Parameter Oksigen terlarut atau Dissolved Oxygen merupakan salah satu parameter yang dapat mewakili pencemaran yang terjadi di Waduk Jatiluhur karena menggambarkan kandungan oksigen yang tersedia yang dibutuhkan makhluk hidup di dalamnya untuk berfotosintesis. Jika kandungan DO rendah maka makhluk hidup yang terdapat didalamnya tidak dapat berfotosintesis dan terancam mati.

Oleh karena itu, dilakukan kajian-kajian penyebab menurunnya kualitas air waduk dari kegiatan yang dilakukan di dalam wilayah Waduk Jatiluhur yang menjadi salah satu masalah besar dan belum dapat terselesaikan sampai saat ini yaitu semakin banyaknya jumlah Keramba Jaring Apung (KJA).

Berdasarkan data dari PJT II, jumlah Keramba Jaring Apung (KJA) dari tahun ke tahun semakin meningkat.Hal ini masih menjadi masalah utama di Waduk Jatiluhur dan berhubungan dengan kualitas air waduk yang mengalami penurunan dari tahun ke tahun.
Tabel 2.Data Populasi Keramba Jaring Apung (KJA) di Waduk Jatiluhur Tahun 2014-2019

\begin{tabular}{cc}
\hline Tahun & Populasi Petak \\
\hline 2014 & 21.579 \\
2015 & 20.752 \\
2016 & 23.746 \\
2017 & 25.951 \\
2018 & 25.951 \\
2019 & 24.415 \\
\hline
\end{tabular}

Sumber: Perum Jasa Tirta II Jatiluhur, Purwakarta

Di titik sampling nomor satu, dua, tiga dan empat mengalami jumlah paling rendah pada tahun 2018 sampai pada tahun ini. Hal tersebut disebabkan semakin meningkatnya jumlah KJA pada tahun tersebut mengakibatkan penurunan kualitas air waduk.

Salah satu indikator bahwa kualitas air Waduk Jatiluhur masih baik adalah dari konsentrasi oksigen terlarut (DO) yang menunjukkan $\geq 6$ mg/L. Sesuai baku mutu badan air kelas I (PP 82 Tahun 2001) konsentrasi oksigen terlarut (DO) minimum adalah $\geq 6 \mathrm{mg} / \mathrm{L}$. Konsentrasi DO di outlet KJA lebih rendah dibandingkan dengan di inlet KJA, konsentrasi di Inlet tahun 2011 yaitu 6,96 mg/L sedangkan di Outlet pada tahun 2019 yaitu $3,72 \mathrm{mg} / \mathrm{L}$. Hal ini menunjukkan bahwa terdapat proses deoksigenasi di waduk.

Berdasarkan hasil pengukuran pada tahun 2014 konsentrasi DO masih menunjukkan nilai diatas $6 \mathrm{mg} / \mathrm{L}$, sedangkan pada tahun 2015 dan 2016 menunjukkan sedikit penurunan konsentrasi DO dan mengalami penurunan yang sangat signifikan pada tahun 2018 sampai saat ini. Rendahnya konsentrasi DO diduga dipengaruhi oleh adanya peningkatan jumlah KJA yang menghasilkan limbah dari kegiatan KJA itu sendiri dan unit-unit KJA yang berfungsi sebagai tempat tinggal dan warung mengakibatkan peningkatan beban pencemaran dan menurunkan kualitas air waduk. 


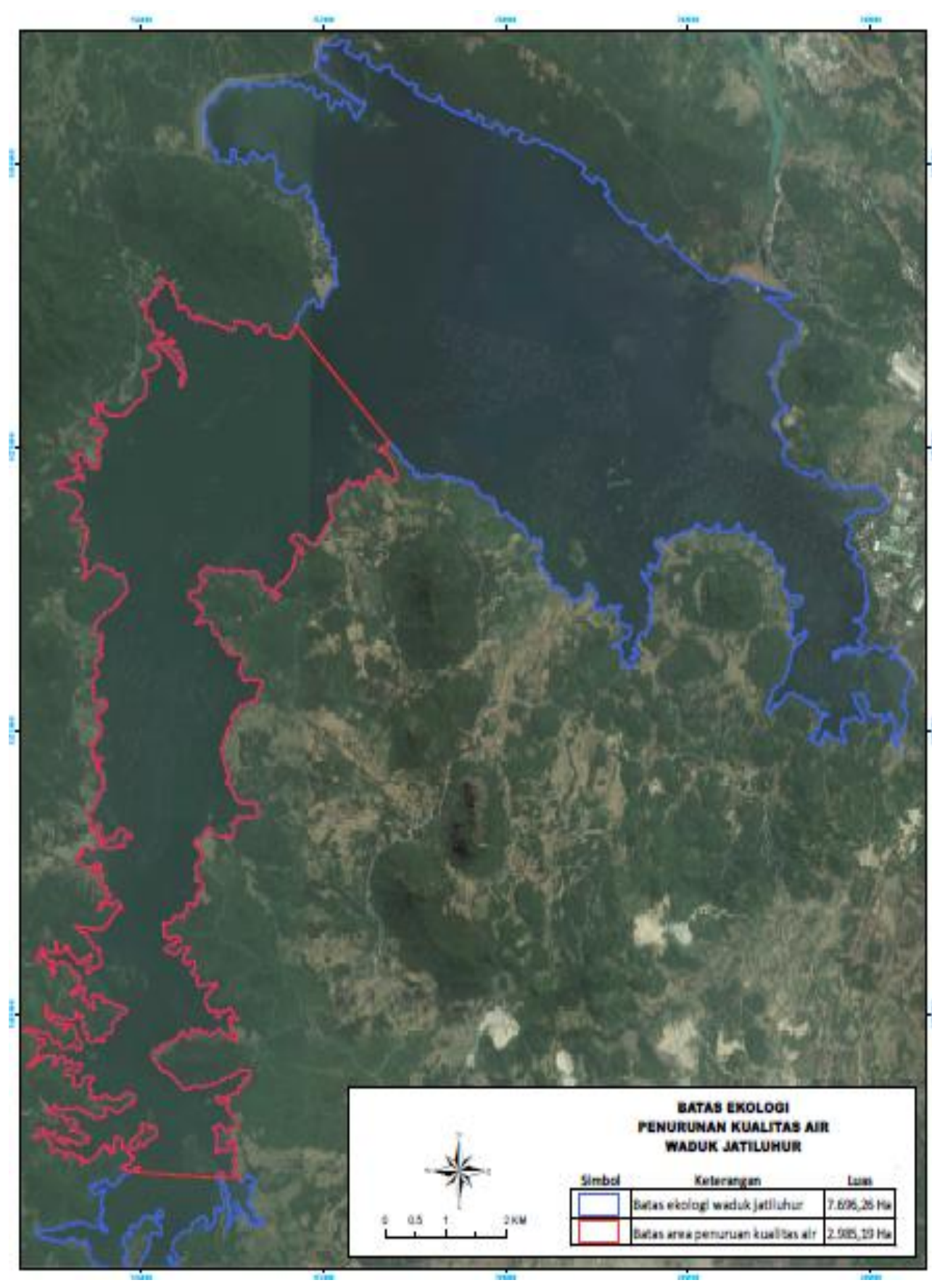

Gambar 3.Peta Batas Ekologi Penurunan Kualitas Air Waduk Jatiluhur

Limbah yang ditimbulkan akibat kegiatan KJA antara lain berasal dari :

a. Kegiatan penghuni KJA seperti MCK dan sampah padat.

Jumlah KJA pada tahun 2009 sekitar 19.845 petak atau sekitar 2.835 unit, apabila setiap unit dijaga minimal 2 orang, maka total penghuni KJA diperkirakan sekitar 5.670 orang, maka total buangan limbah dari kegiatan MCK dan sampah padat akan menimbulkan masalah pencemaran tersendiri.

b. KJA yang tidak beroperasi lagi 
c. Bekas KJA yang rusak seperti drum bekas, bambu dan plastik dibiarkan mengapung diperairan

d. Sisa bahan bakar dan oli dari transportasi air

e. Sisa pakan ikan yang tidak dikonsumsi

f. Metabolism ikan

g. Kematian ikan massal akibat fenomena upwelling

h. Sampah dari tumbuhan/pohon mati sisa hasil panen atau kegiatan pertanian dibantaran waduk.

Menurut Peraturan Pemerintah Nomor 82 Tahun 2001 tentang Pengelolaan Kualitas Air dan Pengendalian Pencemaran Air, klasifikasi mutu air kelas 2 yaitu air yang peruntukannya dapat digunakan untuk prasarana/sarana rekreasi air, pembudidayaan ikan air tawar, peternakan, air untuk mengairi pertanaman, dan atau peruntukan lain yang mempersyaratkan mutu air yang sama dengan kegunaan tersebut harus $\geq 4 \mathrm{mg} / \mathrm{L}$.

Air waduk masih memenuhi baku mutu kelas II pada tahun 2014 sampai 2017, namun pada 2018 sampai tahun ini mengalami penurunan yang sangat signifikan. Hal tersebut diakibatkan semakin banyaknya beban pencemaran ditambah lagi dengan meningkatnya kegiatan keramba jaring apung dari tahun ke tahun.

Angka tingkat pencemaran di Waduk Jatiluhur berdasarkan konsentrasi DO tiap tahunnya semakin tinggi seiring semakin meningkatnya jumlah keramba jaring apung di wilayah tersebut. Dilihat dari tingkat pencemaran berdasarkan konsentrasi DO di outlet yang lebih tinggi dari tingkat pencemaran di outlet KJA yang ditujukan dengan semakin rendahnya konsentrasi DO di outlet KJA dibandingkan di inlet KJA. Hal tersebut menunjukkan bahwa kegiatan keramba jaring apung berpengaruh terhadap penurunan kualitas air bendungan Ir. H. Djuanda (Waduk Jatiluhur). Kondisi anoksik dapat mengakibatkan kondisi perikanan memburuk (Effendi dkk., 2012).
Pada tahun 2014 dengan jumlah KJA 21.579 petak dan tingkat pencemaran $473,50 \mathrm{mg} /$ detik, sedangkan tingkat pencemaran pada tahun 2015 melalui parameter DO menunjukkan adanya tingkat pencemaran di Waduk Jatiluhur dari tahun ke tahun. Jika dilihat jumlah KJA yang semakin meningkat pada tahun 2016 sampai 2018 yaitu dari 23.746 petak menjadi 25.951 petak menggambarkan semakin tinggi pula minat masyarakat yang membuat keramba jaring apung di wilayah Waduk Jatiluhur, Purwakarta. Namun dengan semakin meningkatnya jumlah KJA, ternyata banyak berdampak buruk pada kualitas air waduk tersebut.Hal ini ditunjukkan dengan meningkatnya tingkat pencemar dari tahun ke tahu.

Dengan nilai $\mathrm{K}$ yang didapat melalui parameter DO, dari tahun 2014 sampai tahun 2019 mengalami peningkatan pencemaran sampai tahun 2019 yaitu dengan nilai $\mathrm{K}=5,13 \times 10^{-6}$ \% waktu, menunjukkan bahwa kondisi perairan di wilayah Waduk Jatiluhur mengalami penurunan kualitas air yang sangat signifikan dan mengakibatkan air waduk tersebut tidak dapat dimanfaatkan oleh masyarakat sebagaimana mestinya.

Tingkat beban pencemaran dari tahun ketahun semakin meningkat yaitu pada akhir tahun 2011 sebesar 472,50 mg/detik sedangkan pada tahun 2019 sebesar 512,89 mg/detik.

Pencemaran ini di Waduk Jatiluhur didominasi limbah bahan organik dari keramba jaring apung misal dari pakan ikan saja jika tiap harinya diasumsikan dalam 1 petak menghabiskan $5 \mathrm{~kg}$ pakan ikan, maka jika dikalikan dengan jumlah petak dalam 1 zona berdasarkan standar yang ditentukan yaitu 2.100 petak, maka 2.100 petak x $5 \mathrm{~kg}=10.500 \mathrm{~kg}$ perhari. Jika dikali dengan $40 \%$ asumsi sisa pakan yang tidak termakan dan mengendap ke dasar waduk maka $40 \%$ x 10.500 $\mathrm{kg}=4200 \mathrm{~kg}$ pakan ikan yang tidak termakan dan mengendap setiap harinya. Pencemaran organik akan meningkatkan nilai BOD 
(biochemical oxygen demand) pada perairan (Yustiani dkk., 2019)

Terjadinya perbedaan tingkat pencemaran tiap tahunnya diakibatkan setiap tahun di Waduk Jatiluhur pada bulan-bulan Oktober, November, Desember dan Januari adalah musim peralihan atau pancaroba yang antara lain ditandai dengan hujan yang terus menerus dengan curah hujan tinggi, terbatasnya sinar matahari, angin kencang, ombak besar, berubahnya kecepatan dan pola arus air waduk, terjadi umbalan atau arus balik, serta munculnya Mycrocystis sp. Siklus ini dari tahun ke tahun selalu sama sejak tahun 1978 sampai sekarang, musim pancaroba tersebut telah terbukti berdampak negatif terhadap budidaya ikan dengan KJA sehingga terjadi pencemaran pada air waduk tersebut.

Jika kondisi seperti ini terus dibiarkan, maka akan terjadi pencemaran yang semakin meningkat dan tidak dapat dikendalikan dan hal yang paling buruk yang dapat terjadi adalah sedimentasi atau pendangkalan air Waduk Jatiluhur yang akan berpengaruh pada volume waduk yang semakin menurun. Daya guna waduk yang semula diperkirakan dapat lama, ternyata baru beberapa tahun saja sudah tidak berfungsi lagi dan akan berdampak buruk bagi lingkungan sekitar dan masyarakat yang menggantungkan hidupnya dari Waduk Jatiluhur. Selain itu, akan terjadi kerusakan ekosistem perairan misalnya habitat dan tempat bertelur ikan akan hilang atau hancur akibat sedimentasi yang berlebih dari tanah-tanah hasil proses erosi dari hulu waduk.

Oleh karena itu, perlu dilakukan upaya pengendalian jumlah Keramba Jaring Apung (KJA) di wilayah Waduk Jatiluhur dan dilakukan pemantauan kualitas air secara rutin dan penelitian KJA lanjutan pada masingmasing zona KJA untuk melihat tingkat pencemaran yang terjadi dan untuk menghindari terjadinya bahaya kematian ikan massal akibat fenomena upwelling dan perubahan kualitas air serta mengetahui tingkat penurunan daya dukung lingkungan waduk terutama di sekitar Keramba Jaring Apung.

\section{Kesimpulan}

Berdasarkan kajian ini, diperoleh beberapa kesimpulan yaitu:

1. Konsentrasi DO di outlet KJA lebih rendah dibandingkan dengan di inlet KJA, konsentrasi di Inlet tahun 2011 yaitu 6,96 mg/L sedangkan di Outlet pada tahun 2019 yaitu $3,72 \mathrm{mg} / \mathrm{L}$.

2. Tingkat Pencemaran dari tahun ketahun semakin meningkat yaitu pada akhir tahun 2011 sebesar 472,50 mg/detik sedangkan pada tahun 2019 sebesar 512,89 mg/detik.

3. Keramba jaring apung berpengaruh terhadap penurunan kualitas air Bendungan Ir. H. Djuanda (Waduk Jatiluhur) dengan persentase antara tahun 2014 dan 2019 yaitu $7,87 \%$ dan tidak layak digunakan untuk air baku.

\section{Daftar Pusataka}

Anas, P., Jubaedah, I., Sudino, D. (2016). Kualitas Air dan Beban Limbah Karamba Jaring Apung di Waduk Jatiluhur Jawa Barat. Jurnal Penyuluhan Perikanan dan Kelautan, 11(1): 35-47.

Deswati, R.H., Adrison, V. (2018). Eksternalitas Produksi Karamba Jaring Apung Waduk Jatiluhur, Jurnal Ilmu Ekonomi dan Pembangunan, vol. 19 (1): 49-62

Effendi, H., Adiwilaga, E.M., Sinuhaji, A. (2012). Pengaruh Pencampuran Air terhadap Oksigen Terlarut di Sekitar Karamba Jaring Apung, Waduk Cirata, Purwakarta, Jawa Barat, Ecolab, 6(1): 1-60.

Manik, K.E.S. (2009). Pengelolaan Lingkungan Hidup. Jakarta: Djambatan. 
Suharto, B., Dewi, L., Mustaqiman, A.N., Marjo, T.R.A.K. (2019). The Study of Water Quality Status in the Ngebrong River with Physical and Chemical Parameters in the Tawangsari Barat Region, Pujon District, Malang Regency, Indonesian Journal of Urban and Environmental Technology, vol. 2(2): 164-180.
Yustiani, Y.M., Wahyuni, S., Kadir, A.A.A. (2019). Identifikasi Nilai Laju Deoksigenasi di Daerah Padat Penduduk (Studi Kasus Sungai Cicadas, Bandung), Journal of Community Based Environmental Engineering and Management, vol. 3 (1): 9-14. 